\title{
Cytomorphological Studies in Some Species of Setaria L. from Different Phytogeographical Parts of India
}

\author{
Harpreet Kaur*, Harbans Singh, Nadeem Mubarik , Santosh Kumari, \\ Raghbir Chand Gupta and Manjit Inder Singh Saggoo \\ Department of Botany, Punjabi University, Patiala 147 002, India
}

Received February 3, 2011; accepted May 18, 2011

\begin{abstract}
Summary At present, meiotic studies have been carried out on a population basis for assessing the genetic diversity in 38 accessions belonging to 6 species, namely $S$. barbata $(n=18), S$. glauca $(n=9,18,36)$, S. megaphylla $(n=18), S$. palmifolia $(n=18,27), S$. tomentosa $(n=18)$ and S. verticillata $(n=27)$, of the genus Setaria from different parts of India. For S. barbata and S. megaphylla, the chromosomal counts of $n=18$ represent the first reports from India. For S. glauca, 3 cytotypes occurring as diploids, tetraploids and octaploids are reported which also show some marked differences in their morphological features. The meiotic behavior in some populations of S. barbata and S. palmifolia $(n=27)$ was found to be highly abnormal with low pollen fertility.
\end{abstract}

Key words Chromosome number, Cytomorphology, Intraspecific cytotypes, Setaria.

The genus Setaria L., commonly known as bristle grass or foxtail millet, belongs to the tribe Paniceae of family Poaceae and includes 140 species (Airy Shaw 1973) distributed throughout the temperate and tropical regions of the world. In India, the genus is represented by 17 species (Bor 1960). It is characterized as an annual or perennial grass with stem tufted cane-like spikelets clustered on narrowely pyramidal panicles which bears a persistent involucre of a few or many barbed bristles; glumes 4 membranous and styles quite distinct. Several species of genus Setaria, such as S. italica and S. longiseta, give abundant coarse hay of inferior quality. S. flavida and S. sphacelata are mainly used as fodder. The young shoots of a few species are eaten as salads in Malaysia. In West China, India, Pakistan, and South Russia, they are eaten as whole grain, ground into flour, or consumed in sprouted form (Schery 1972). In Luzon, North Philippines, S. palmifolia is used to cure skin disorders (Bodner and Gereau 1988). Some of the species carry negative features, for example $S$. viridis grows as a weed in temperate regions and other species serve as hosts for maize and sugarcane mosaic viruses (Mabberley 1998). A perusal of literature brings to light the existence of lot of intra- and interspecific chromosomal diversity in the genus from different parts of the world. To supplement this information further, with from information a wide area throughout India, a population-based cytomorphological study has been carried out on new and unexplored areas in different states of India.

Materials and methods

\section{Morphological studies}

In the case of $S$. glauca, all 26 morphometric characters were studied for each cytotype, in order to have proper insight into morphological variation. For stomata studies, mature leaves were treated with potassium hydroxide $(\mathrm{KOH})$ and epidermal peels were then observed. Stomatal size

\footnotetext{
*Corresponding author, e-mail: harpreetsidhu75@gmail.com; harpreetsidhu13@rediffmail.com
} 
was measured using an occulomicrometer.

\section{Cytological studies}

Materials for the meiotic study were collected from 38 populations belonging to different species of Setaria, growing at various places in North Indian plains, such as Punjab and Haryana, hilly areas of Madhya Pradesh in Central India, such as district Hoshangabad, Himachal Pradesh districts, such as Kangra and Sirmaur, and extreme areas of North Western Himalayas, such as Kashmir (Table 1). Voucher specimens are deposited in the Herbarium, Department of Botany, Punjabi University, Patiala (PUN). Meiotic studies were carried out through a standard smearing technique from young panicles fixed in Carnoy's fixative. For the analysis of meiotic abnormalities, a large number of PMCs were observed for each type of anomaly. Pollen fertility was estimated through glyceroacetocarmine stainability. Well-filled pollen grains with stained nuclei were taken as apparently viable/fertile, while shrivelled and unstained pollen grains were counted as sterile. Pollen grain size was measured using an occulomicrometer. Photomicrographs of chromosome counts were made from freshly prepared slides using a Nikon 80i eclipse Digital Imaging System.

\section{Results}

At present, detailed meiotic studies have been made on 38 accessions belonging to 6 species of the genus Setaria. The data regarding the major area of collection with exact localities, altitude, accession numbers, present and previous meiotic chromosome numbers, ploidy level and meiotic course are provided in Table 1.

Setaria barbata (Lamk.) Kunth (=Chaetochloa barbata (Lam.) A. S. Hitchc. \& Chase=Chaetochloa barbata (Lam.) Hitchc. \& Chase=Panicum barbatum (Lam.))

The species is commonly known as bristly foxtail grass and is distributed in tropical Asia and Africa. It is a good pasture grass. The population worked out at present is found to be common on slopes and roadsides in Himachal Pradesh an within an altitudinal range of 600-2,500 m. The species is characterized by: its annual habit; its upper glume which is half to three quarters the length of the upper lemma; and the branches of its panicle, which are divided from the base, and bear short racemes and spikelets which are elliptic-acute and crowded. Cytologically speaking, this grass with $n=18$ (Fig. 1) is found to be tetraploid. Out of 4 populations studied at present, 1 population, from Dharamsala, showed abnormal meiotic behaviour in the form of multivalent formation at M-I (Fig. 2), unoriented bivalents at M-I (Fig. 3), the presence of bridges (Fig. 4) and laggards (Fig. 5) at A-I, abnormal microsporogenesis showing diads (Fig. 6) and triads (Fig. 7), pollen grains of unequal size (Fig. 8) and reduced, pollen fertility at 44\% (Fig. 9).

Setaria glauca (L.) P. Beauv. (=Panicum glaucum L.)

The species, commonly called yellow bristle grass, pearl millet or yellow foxtail, is found mostly in cultivated fields. It is distributed in all temperate and tropical regions. It is characterized by spike cylindrical; spikelets $3 \mathrm{~mm}$ long and upper lemma coarsely rugose, boat-shaped, slightly keeled. Cytologically, 24 populations have been worked out from different phytogeographical regions of India. All the populations depict normal meiotic behaviour and high pollen fertility. Out of these, 11 populations are found to be at diploid level $(n=9), 8$ at tetraploid level $(n=18)$ and 5 at octaploid level $(n=36)$ based on $x=9$. Distributional and morphological comparisons have been made in these cytotypes in the present study (Table 2).

Two accessions from Madhya Pradesh, 2 from Punjab, 3 from Haryana, 1 from Rajasthan, 1 from Himachal Pradesh and 2 from Kashmir occur at the diploid level with $n=9$ (Fig. 25a). Two accessions from Madhya Pradesh, 3 from Punjab and 3 from Himachal Pradesh exhibit the tetraploid 
Table 1. Information about area, locality, altitude, accession number, meiotic chromosome number reports, ploidy level and meiotic course of different species of Setaria from different parts of India

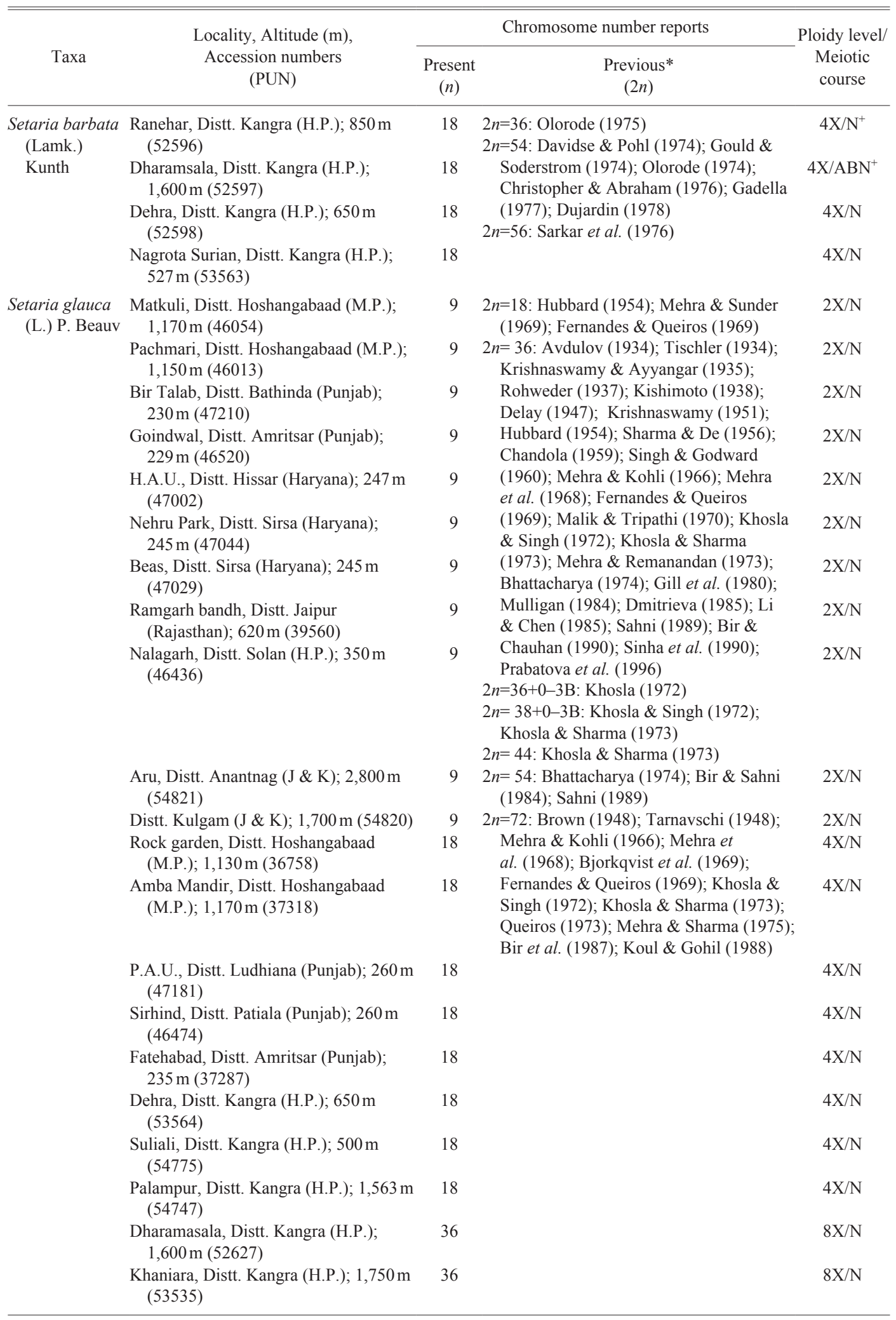


Table 1. (Continued)

\begin{tabular}{|c|c|c|c|c|}
\hline \multirow[b]{2}{*}{ Taxa } & \multirow{2}{*}{$\begin{array}{l}\text { Locality, Altitude (m), } \\
\text { Accession numbers } \\
\text { (PUN) }\end{array}$} & \multicolumn{2}{|r|}{ Chromosome number reports } & \multirow{2}{*}{$\begin{array}{c}\text { Ploidy level/ } \\
\text { Meiotic } \\
\text { course }\end{array}$} \\
\hline & & $\begin{array}{l}\text { Present } \\
(n)\end{array}$ & $\begin{array}{l}\text { Previous* } \\
\quad(2 n)\end{array}$ & \\
\hline & $\begin{array}{l}\text { Chhota Bhangal, Distt. Kangra (H.P.); } \\
2,000 \mathrm{~m}(53536)\end{array}$ & 36 & & $8 \mathrm{X} / \mathrm{N}$ \\
\hline & $\begin{array}{l}\text { Bhanala, Distt. Kangra (H.P.); } 800 \mathrm{~m} \\
\text { (54746) }\end{array}$ & 36 & & $8 \mathrm{X} / \mathrm{N}$ \\
\hline & $\begin{array}{l}\text { Swad, Distt. Kangra (H.P.); 2,500 m } \\
\text { (54748) }\end{array}$ & 36 & & $8 \mathrm{X} / \mathrm{N}$ \\
\hline \multirow{2}{*}{$\begin{array}{l}\text { Setaria } \\
\quad \text { megaphylla } \\
\text { (Steud.) } \\
\text { Dur.\& } \\
\text { Schinz. }\end{array}$} & $\begin{array}{l}\text { Bhagsunaag, Distt. Kangra (H.P.); } \\
\text { 1,650 m (52599) }\end{array}$ & 18 & $\begin{array}{l}\text { 2n=36: Kammacher et al. (1973); Olorode } \\
\quad \text { (1975); Dujardin (1978) }\end{array}$ & $4 \mathrm{X} / \mathrm{N}$ \\
\hline & $\begin{array}{l}\text { Khaniara, Distt. Kangra (H.P.); } 1,750 \mathrm{~m} \\
(52600)\end{array}$ & 18 & $\begin{array}{l}2 n=54: \text { Spies \& Plessis (1987); Hoshino \& } \\
\quad \text { Davidse (1988) }\end{array}$ & $4 \mathrm{X} / \mathrm{N}$ \\
\hline \multirow{2}{*}{$\begin{array}{l}\text { Setaria } \\
\text { palmifolia } \\
\text { Stapf }\end{array}$} & $\begin{array}{l}\text { Matkuli, Distt. Hoshangabaad (M.P.); } \\
\quad 400 \mathrm{~m}(46325)\end{array}$ & 18 & $\begin{array}{l}2 n=36: \text { Khosla \& Sharma }(1973) \\
2 n=54: \text { Krishnaswamy }(1951)\end{array}$ & $4 \mathrm{X} / \mathrm{N}$ \\
\hline & $\begin{array}{l}\text { Bhanala, Distt. Kangra (H.P.); } 800 \mathrm{~m} \\
\text { (54819) }\end{array}$ & 27 & $\begin{array}{l}\text { Krishnaswamy et al. (1954); Tateoka } \\
\text { (1955, 1956); Singh \& Godward (1960); } \\
\text { Larsen (1963); Khosla \& Sharma } \\
\text { (1973); Bhattacharya (1974); Gould \& } \\
\text { Soderstrom (1974); Mehra \& Sharma } \\
\text { (1975); Christopher \& Abraham (1976) }\end{array}$ & $6 \mathrm{X} / \mathrm{ABN}$ \\
\hline \multirow{4}{*}{$\begin{array}{l}\text { Setaria } \\
\quad \begin{array}{l}\text { tomentosa } \\
\text { (Roxb.) }\end{array} \\
\text { Kunth= } \\
\text { Setaria } \\
\text { intermedia } \\
\text { (Roth) } \\
\text { Roem. } \\
\text { Schult. }\end{array}$} & $\begin{array}{l}\text { Ranehar, Distt. Kangra (H.P.); } 850 \mathrm{~m} \\
\quad(53575)\end{array}$ & 18 & $\begin{array}{l}2 n=18: \text { Sindhe }(1977) \\
2 n=36: \text { Gupta (1963); Mitra \& Datta }\end{array}$ & $4 \mathrm{X} / \mathrm{N}$ \\
\hline & $\begin{array}{l}\text { Polo garden, Distt. Hoshangabaad } \\
\text { (M.P.); } 1,060 \mathrm{~m}(46050)\end{array}$ & 18 & $\begin{array}{l}\text { (1967); Gupta (1969); Malik \& Tripathi } \\
\text { (1970); Saxena \& Gupta (1970); Gupta }\end{array}$ & $4 \mathrm{X} / \mathrm{N}$ \\
\hline & $\begin{array}{l}\text { Pachmari, Distt. Hoshangabaad (M.P.); } \\
\text { 1,040m (46291) }\end{array}$ & 18 & $\begin{array}{l}\text { \& Yashvir (1971); Khosla \& Sharma } \\
\text { (1973); Mehra \& Remanandan (1973); }\end{array}$ & $4 \mathrm{X} / \mathrm{N}$ \\
\hline & $\begin{array}{l}\text { P.A.U., Distt. Ludhiana (Punjab); } 211 \mathrm{~m} \\
\quad(47183)\end{array}$ & 18 & $\begin{array}{l}\text { Gould \& Soderstrom (1974); Mehra \& } \\
\text { Sharma (1975); Sinha \& Gupta (1977); } \\
\text { Gill et al. (1980); Bir et al. (1987); Sinha } \\
\text { et al. (1990) } \\
\text { 2n=38: Bir \& Sahni (1983) }\end{array}$ & $4 \mathrm{X} / \mathrm{N}$ \\
\hline \multirow{2}{*}{$\begin{array}{l}\text { Setaria } \\
\quad \text { Verticillata } \\
\text { (L.) P. } \\
\text { Beauv. }\end{array}$} & $\begin{array}{l}\text { Suliali, Distt. Kangra (H.P.); } 500 \mathrm{~m} \\
\quad(54777)\end{array}$ & 27 & $\begin{array}{l}2 n=18: \text { Krishnaswamy \& Ayyangar (1935); } \\
\quad \text { Sharma \& De (1956); Tateoka (1965); }\end{array}$ & $6 \mathrm{X} / \mathrm{N}$ \\
\hline & $\begin{array}{l}\text { Nagrota Surian, Distt. Kangra (H.P.); } \\
527 \mathrm{~m}(52631)\end{array}$ & 27 & $\begin{array}{l}\text { Mehra \& Kohli (1966); Mehra et al. } \\
\text { (1968); Fernandes \& Queiros (1969); } \\
\text { Bhattacharya (1974); Sahni (1989); Bala } \\
\text { \& Sachdeva (1990); Ahsaan et al. (1994); } \\
\text { Wu \& Bai (2000) } \\
\text { 2n=36: Parodi (1946); Chandola (1959); } \\
\text { Platzer (1962); Pohl (1962); Gould } \\
\text { (1966); Mehra \& Kohli (1966); Mehra } \\
\text { et al. (1968); Singh \& Gupta (1977); } \\
\text { Bir \& Sahni (1986); Sahni (1989); Bala } \\
\text { \& Sachdeva (1990); Benabdelmouna et } \\
\text { al.(2001); Benabdelmouna \& Darmency } \\
\text { (2003) } \\
\text { 2n=54: Mehra \& Kohli (1966); Mehra et al. } \\
\text { (1968); Singh \& Gupta (1977); Mehra } \\
\text { (1982); Bir \& Sahni (1983), (1985); Bala } \\
\text { \& Sachdeva (1990); Sinha et al. (1990) } \\
\text { 2n=72: Bir \& Sahni (1986); Sahni (1989) } \\
\text { 2n=108: Raman et al. (1959); Bir \& Sahni } \\
\text { (1986); Sahni (1989) }\end{array}$ & ; \\
\hline
\end{tabular}

*i) Previous chromosome number reports are based on Chromosome Atlases by Fedorov (1974); and Kumar and Subramaniam Vol. II (1986); Index to Plant Chromosome Number Reports from 1968 onwards; various Journals; Proceeding volumes and internet. ii) For compilation purposes, previous chromosome numbers are either originally reported as $2 n$ numbers or calculated as $2 n$ numbers. iii) The references compiled here are not cited in the text, hence details not provided at the end.

${ }^{+} \mathrm{N}=$ Normal Meiosis, $\mathrm{ABN}=$ Abnormal Meiosis 



Figs. 1-21. 1-9. Setaria barbata-1). $\mathrm{PMC}$ at $\mathrm{M}-\mathrm{I}(n=18) ; 2) . \mathrm{PMC}$ at $\left.\mathrm{M}-\mathrm{I}\left(3_{\mathrm{VI}}+2_{\mathrm{IV}}+5_{\mathrm{II}}\right) ; 3\right)$. PMCs showing unoriented bivalents at $\mathrm{M}-\mathrm{I} ; 4)$. PMC showing multiple bridges at A-I; 5). PMC showing laggards at A-I; 6). Diad; 7). Triad; 8). Heterogenous sized fertile pollen grains; 9). Fertile and sterile pollen grains. 10). Setaria megaphylla-PMC at M-I $(n=18) .11-19$. Setaria palmifolia-11). cytotype with $n=18$ : PMC at Diakinesis $(n=18) ; 12-19)$. Cytotype with $n=27$ : 12). PMC at $\mathrm{M}-\mathrm{I}(n=27) ; 13)$. PMC at $\mathrm{M}-\mathrm{I}$ showing interbivalent connections; 14,15). Three and 2 PMCs, respectively showing chromatin transfer at prophase-I stage; 16). A hypoploid PMC left with only 11 bivalents; 17). PMC showing pycnotic chromatin at prophase-I; 18). Diad; 19). Triad. 20). Setaria tomentosa-PMC at M-I ( $n=18) .21)$. Setaria verticillata-PMC at Diakinesis $(n=27)$. Scale $=10 \mu \mathrm{m}$ 
Table 2. Detailed morphological comparison of 3 cytotypes of Setaria glauca from different parts of India

\begin{tabular}{|c|c|c|c|c|}
\hline S. No. & Character & $\begin{array}{l}\text { Diploid } \\
(n=9)\end{array}$ & $\begin{array}{l}\text { Tetraploid } \\
\quad(n=18)\end{array}$ & $\begin{array}{l}\text { Octaploid } \\
(n=36)\end{array}$ \\
\hline 1. & Collection area & $\begin{array}{l}\text { Haryana } \\
\text { Himachal Pradesh } \\
\text { Madhya Pradesh } \\
\text { Punjab } \\
\text { Rajasthan }\end{array}$ & $\begin{array}{l}\text { Himachal Pradesh } \\
\text { Madhya Pradesh } \\
\text { Punjab }\end{array}$ & Himachal Pradesh \\
\hline 2. & Distribution & Frequent & Most Common & Uncommon \\
\hline 3. & Habit & Small sized & Medium sized & Tallest \\
\hline 4. & Habitat & $\begin{array}{l}\text { Found near water or } \\
\text { as pasture grass in } \\
\text { gardens }\end{array}$ & Found along roadsides & Found near water \\
\hline 5. & $\begin{array}{l}\text { Plant } \\
\text { height }(\mathrm{cm}) \\
\underline{\text { Stem }}\end{array}$ & $20-30$ & $40-60$ & $50-80$ \\
\hline 6. & Number of inernodes & $3-4$ & $4-6$ & $6-9$ \\
\hline 7. & $\begin{array}{l}\text { Size of inernode }(\mathrm{cm}) \\
\text { Leaf }\end{array}$ & $2.3-5$ & $4.6-7.2$ & $6.4-10$ \\
\hline 8. & 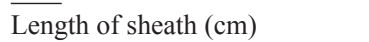 & $3.4-6.4$ & $5.4-7.5$ & $6.5-9.0$ \\
\hline 9. & Length of lamina (cm) & $7-14$ & $12-16$ & $18-22$ \\
\hline 10. & Width of lamina (mm) & $2.5-5.0$ & $3.5-6.5$ & $5.5-8.5$ \\
\hline 11. & Hairyness & Absent & $\begin{array}{l}\text { Present on both } \\
\text { upperand lower sides }\end{array}$ & $\begin{array}{l}\text { Present on upper side } \\
\text { only }\end{array}$ \\
\hline & Leaf blade & & & \\
\hline 12. & $\overline{\text { Leaf tip }}$ & Pointed & Pointed & Pointed \\
\hline 13. & $\begin{array}{l}\text { Leaf base } \\
\text { Ligule }\end{array}$ & Constricted & Tapering & Constricted \\
\hline 14. & $\begin{array}{l}\text { Type of ligule } \\
\text { Stomata }\end{array}$ & A fringe of hairs & A fringe of hairs & A fringe of hairs \\
\hline 15. & $\overline{\operatorname{Size}(\mu \mathrm{m})}$ & $26.83 \times 13.41 \pm$ & $32.48 \times 19.54 \pm$ & $40.40 \times 28.45 \pm$ \\
\hline 16. & $\begin{array}{l}\text { Stomatal frequency on upper/ } \\
\text { lower surface of leaf }\left(\mathrm{mm}^{2}\right)\end{array}$ & & & \\
\hline 17. & $\begin{array}{l}\text { Stomatal index of upper/ lower } \\
\text { surface of leaf }(\mu \mathrm{m})\end{array}$ & $5.46 / 3.84 \pm$ & $6.68 / 4.48 \pm$ & $7.54 / 5.20 \pm$ \\
\hline & Inflorescence & $20.34 / 12.44 \pm$ & $22.48 / 13.64 \pm$ & $24.54 / 14.52 \pm$ \\
\hline 18. & Length of spike (cm) & $1-9.5$ & $2-5.3$ & $6.0-10.9$ \\
\hline 19. & Length of spikelet (mm) & $1-2$ & $2-3$ & $2-3.5$ \\
\hline 20. & No. of bristles per spikelet & $10-12$ & $12-13$ & $15-16$ \\
\hline 21. & $\begin{array}{l}\text { Length of involucral } \\
\text { bristles }(\mathrm{mm}) \\
\text { Lemma }\end{array}$ & $3.5-4.5$ & $4-5.5$ & $4.5-7.5$ \\
\hline 22. & $\begin{array}{l}\text { Size }(\mathrm{mm}) \\
\text { Palea }\end{array}$ & $2.0-2.2$ & $2.3-2.5$ & $2.9-3.0$ \\
\hline 23. & $\begin{array}{l}\overline{\text { Size }(\mathrm{mm})} \\
\text { Pollen grains }\end{array}$ & $1.0-1.3$ & $1.3-1.5$ & $1.8-2.0$ \\
\hline 24. & Size $(\mu \mathrm{m})$ & $24.34 \times 22.54$ & $28.53 \times 27.16$ & $36.48 \times 35.19$ \\
\hline 25. & Shape & Oblong & Round & Round \\
\hline 26. & Fertility (\%) & 100 & 100 & 100 \\
\hline
\end{tabular}

level with $n=18$ (Fig. 25b). An other 5 accessions from Himachal Pradesh show the octaploid level with $n=36$ (Fig. 25c).

For the morphological study, 26 parameters have been evaluated for vegetative and reproduc- 

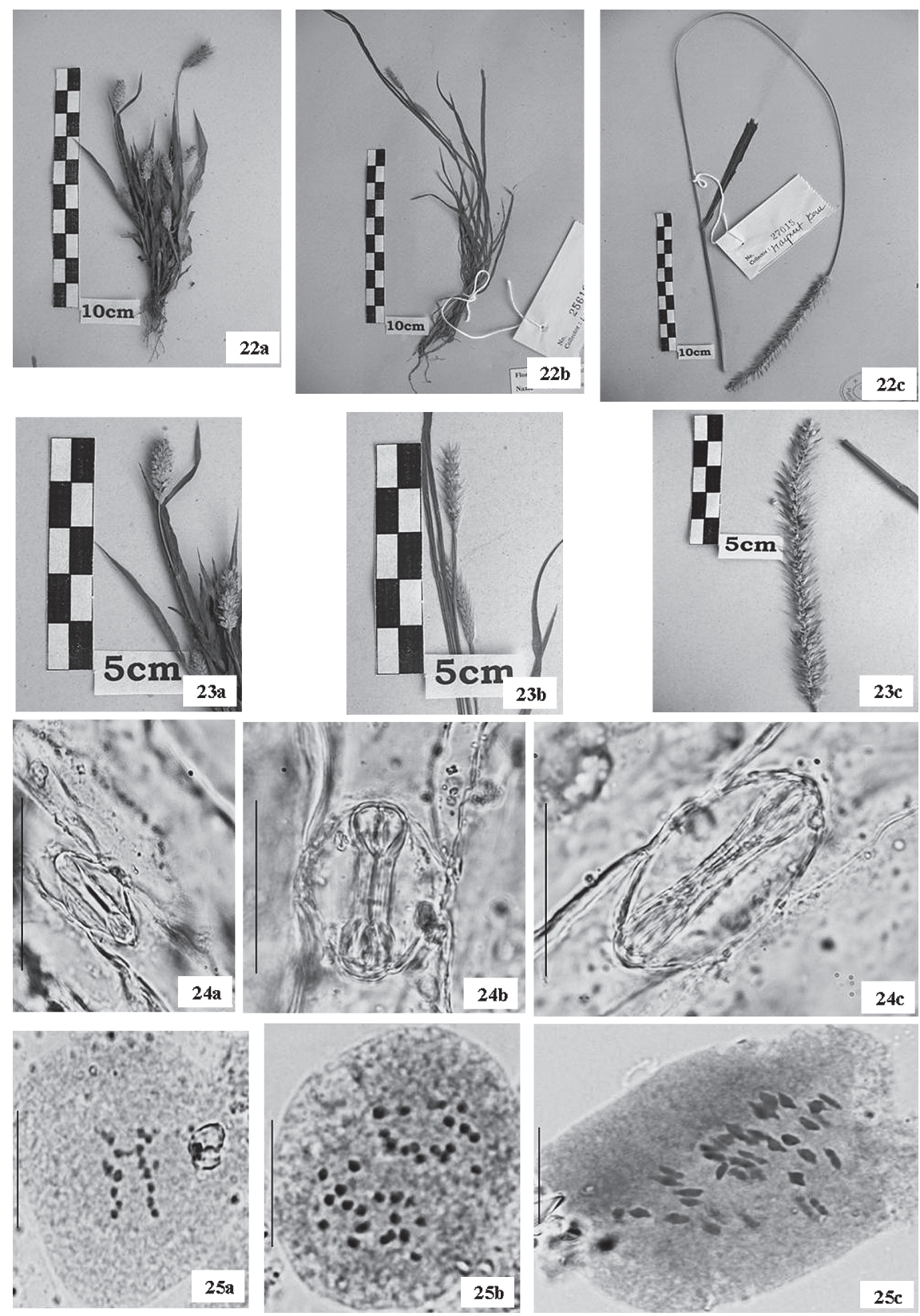

Figs. 22-25. Setaria glauca-22. Plant morphology: 22a). Diploid cytotype; 22b). Tetraploid cytotype; 22c). Octaploid cytotype; 23. Inflorescence: $23 a) .2 x ; 23 b) .4 x ; 23 c) .8 x ; 24$. Stomata: 24a). $2 x ; 24 \mathrm{~b}) .4 x ; 24 \mathrm{c}) .8 x ; 25$. PMCs (Scale $=10 \mu \mathrm{m}): 25 \mathrm{a}) .2 x-\mathrm{A}-\mathrm{I}$ with $n=9 ; 25 \mathrm{~b}) .4 x-\mathrm{A}-\mathrm{I}$ with $n=18 ; 25 \mathrm{c})$. M-I with $n=36$.

tive characteristics of all the 3 cytotypes (Table 2). Significant morphological differences are noted for characteristics such as plant height (Fig. 22), length of spike (Fig. 23) and spikelets, as well as leaves - size of sheath, lamina, stomata (Fig. 24) and stomatal index.

The species is commonly known as Malaysian palm grass. It is distributed in tropical Africa 
on a world-wide basis. This species has been introduced into India. The presently worked out population is found to be common in shady moist places along the roadsides between altitudes of $800-2,000 \mathrm{~m}$ in Himachal Pradesh. It is characterized by its perennial habit, spikelets less secund on branches, and an upper glume half as long as the upper lemma or less. The species depicts a normal meiotic course with $n=18$ (Fig. 10) and is at tetraploid level.

\section{Setaria palmifolia Stapf}

The species is distributed in tropical areas on a world-wide basis. The presently worked out populations are found scrambling over other vegetation, often in dense and shady places. It is a robust grass and characterized by inflorescence $25-30 \mathrm{~cm}$ long, spikelets which are $3 \mathrm{~mm}$ long and bristle twice as long as the spikelet. Cytologically speaking, 2 cytotypes, occurring as a tetraploid with $n=18$ (Fig. 11) and a hexaploid with $n=27$ (Fig. 12), respectively, are reported. For the tetraploid cytotype, the meiotic course has been found to be normal, whereas for the hexaploid cytotype, meiotic behavior has been reported to be abnormal with the presence of interbivalent connections at M-I (Fig. 13); cytomixis at prophase-I (Figs. 14, 15), the production of hypo and hyperploids PMCs (Fig. 16) and extrachromatin masses lying away from the main chromatin material (Fig. 17). Abnormal microsporogensis results in the production of diads (Fig. 18) and triads (Fig. 19) besides normal tetrads with reduced pollen fertility (58\%). Morphologically, both cytotypes were indistinguishable.

Setaria tomentosa $($ Roxb. $)$ Kunth $(=$ S. intermedia Roth. $=$ Panicum tomentosum=Panicum tomentosum Roxb.)

The species is widely distributed in the plains and hills of India. The presently worked out populations are usually found in damp and shady places in Punjab, Himachal Pradesh and Madhya Pradesh. It is characterized by its annual habit, narrow panicle and spikelets, crowded or loosely scattered, at $2 \mathrm{~mm}$ long. The meiotic course has been found to be normal with PMCs showing $n=18$ (Fig. 20) at tetraploid level.

Setaria verticillata (L.) P. Beauv. (=Chaetochloa verticillata (L.) Scribn.=Panicum verticillatum L. =Setaria carnei $A$. S. Hitchc.)

The species is commonly known as rough bristle grass or bristly foxtail and is found to be invasive species. It is distributed in tropical and temperate regions of the old world. The presently worked out populations are found to be common in open and waste places at an altitudinal range of 300-800 m in Himachal Pradesh. Flowering and fruiting occurs throughout the year. This species can be easily recognized because of its clinging, extrorsely barbed bristles on loose and lobed panicles. The gametic number is noted to be $n=27$ (Fig. 21) and it is at hexaploid level.

\section{Discussion}

The genus Setaria, has attracted the attention of cytologists throughout the world starting with reports of $2 n=18$ for $S$. italica for Chinese material and $2 n=36$ for S. plicata for tropical Asian material by Avdulov (1928). Since then, 71 species on a world-wide basis, including all the 17 taxonomically known species from India, have been cytologically worked out.

On the basis of data compiled for cytological observations pertaining to the genus Setaria, it is observed that some of the species represent even intraspecific cytotypes and depict chromosome numbers in the range of $2 n=14$ to 108 with $2 n=36$ being most frequent ( $48 \%$ ), followed by $2 n=18$ and $2 n=54$, in an almost equal frequency of nearly $18 \%$, with $2 n=72$ also counted as significant (11\%). From India, all 17 species have been cytologically worked out, with nearly half the number of species exhibiting multiple cytotypes with chromosome numbers such as $2 n=14,18,20,28,36$, 
$38,40,44,54,56,72$, with highest frequency being $2 n=36(20 \%)$ followed by $2 n=18$ and $2 n=27$ at nearly the same frequency of $14 \%$.

On the basis of the present and previous reports on chromosome number for the species studied at present, $x=9$ remains the common base number, as observed for the genus Setaria and its tribe Paniceae by Brown (1948). Calculating by this monobasic nature, the presently worked out populations represent $28 \%$ diploids and $72 \%$ polyploids, in confirmity with the statement of Canahan and Hill (1961) that about $80 \%$ of the known grass species are polyploids. Although on a world-wide basis the highest level reported so far in this genus is $12 x$, in the present collections the maximum level observed is $8 x$. Aneuploids are also present in some species but at a very low frequency.

Further scrutiny of literature shows that diploids and polyploids of Setaria exhibit overlapping patterns of distribution in India. However, it has been seen at present that tetraploids are of relatively wider distribution. Taking $S$. glauca into consideration, it is interesting to note that octaploids exist only in district Kangra of Himachal Pradesh, emphasizing the phytogeographical distributional preference of the cytotype.

For $S$. barbata, the present count of $n=18$ at tetraploid level has been worked out for the first time from India, in confirmity with the earlier report of $2 n=36$ by Olorode (1975) from Nigeria. Other reports of hexaploids with $2 n=54$, from outside India by Gadella (1977) and Dujardin (1978) and from South India by Christopher and Abraham (1976), as well of aneuploids at $6 x$ level with $2 n=56$ by Sarkar et al. (1976), from the eastern part of India, have already been published. Out of 4 accessions, 1 accession of $S$. barbata shows an abnormal course of meiosis accompanied by pollen sterility. Singh and Gupta (1977) also observed multivalents in S. macrostachya and suggested it to be a case of segmental allopolyploidy.

For S. glauca, morphological variations of the 3 cytotypes indicate there to be marked increases in certain characteristics, especially size of plant, leaves and inflorescence, in parallel with an increase in the level of ploidy. Even some of the microcharacteristics like stomatal size, size of PMCs and size of pollen grains, also show proportionate increase with this change in ploidy at the intraspecific level. Similar inference has been drawn by comparing only 2 cytotypes, $4 x$ and $8 x$, by Mehra et al. (1968). Cytologically speaking, on the basis of the cumulative literature, the species is reported to exhibit $2 n=18,36,36+0-3 \mathrm{~B}, 38+0-3 \mathrm{~B}, 44,54,72$ chromosome numbers, suggesting the existence of intraspecific polyploidy cytotypes $(2 x, 4 x, 6 x$ and $8 x)$. For $S$. megaphylla, the chromosome count of $n=18$ is the first record for the species from India and simultaneously lies in confirmity with earlier reports by Olorode (1975) from Nigeria and Dujardin (1978) from Zaire while differing from hexaploid reports of $2 n=54$ by Spies and Du Plessis (1987) and Hoshino and Davidse (1988) from Southern Africa.

For S. palmifolia, the present count of $n=18$ is tetraploid and the meiotically stable cytotype collected from Madhya Pradesh conforms the earlier single report of $2 n=36$ by Khosla and Sharma (1973) from Himachal Pradesh. The other hexaploid and meiotically imbalanced cytotype with $n=27$ studied at present from Himachal Pradesh conforms to earlier reports of $2 n=54$ by many researchers (Table 1).

For $S$. tomentosa, the present report of $n=18$ is in confirmity with multiple reports from different parts of the world, except for a diploid report of $2 n=18$ by Sindhe (1977) from South India and an aneuploid of $2 n=38$ by Bir and Sahni (1983) from the Punjab plains.

For S. verticillata, the presently worked out populations from hilly areas of Himachal Pradesh exhibit $n=27$ at hexaploid level, which is in confirmity with earlier reports of $2 n=54$ by Bir and Sahni $(1983,1985)$ from the Punjab plains, and Sinha et al. (1990) from Bihar. The data on previous reports speaks otherwise, i.e. diploids and tetraploids cytotypes are reported to be very common, hexaploid cytotypes uncommon, and octaploids as well as $12 x$ type cytotypes rare (Table 1 ). 


\section{Acknowledgements}

The authors are grateful to the University Grants Commission, New Delhi for providing financial assistance under the DRS SAP II and ASIST. We are highly thankful to the Joint Director and Deputy Director BSI, Dehra Dun for their help in the identification of plant species.

\section{References}

Airy Shaw, H. K. 1973. A dictionary of Flowering plants and Ferns (Revised 8th ed. of the late J. C. Willis), University Press Cambridge.

Avdulov, N. P. 1928. Systematic Karyology of family Gramineae. Daily Paper All Union Botanists (1928g), L (1): 65-67.

Bir, S. S. and Sahni, M. 1983. SOCGI plant chromosome number reports-I. Cytol. Genet. 18: 58-59.

— and S-, M. 1985. Cytological investigations on some grasses from Punjab Plain, North India. Proc Indian Natl Sci Acad B Biol Sci 5: 609-626.

Bodner, C. C. and Gereau, R. E. 1988. A Contribution to Bontoc Ethnobotany. Econ. Bot. 42(3):307-369.

Bor, N. L. 1960. The Grasses of Burma, Ceylon, India and Pakistan. Pergamon Press,

Brown, W. V. 1948. A cytological study in the Gramineae. Am. J. Bot. 35: 382-396.

Canahan, H. L. and Hill, H. D. 1961. Cytology and genetics of forage grasses. Bot. Rev. 27: 1-162.

Christopher, J. and Abraham, A. 1976. Study on the cytology and phylogeny of South Indian grasses. III. Subfamily VI: Panicoideae, tribe(i) the Paniceae. Cytologia 41: 621-637.

Dujardin, M. 1978. Chromosome numbers of some tropical African grasses from Western Zaire. Can. J. Bot. 56: 21382152.

Gadella, T. W. J. 1977. In IOPB chromosome number reports LVI. Taxon 26: 257-274.

Hoshino, T. and Davidse, G. 1988. Chromosome numbers of grasses (Poaceae) from Southern Africa. I. Ann. Mo. Bot. Gard. 75: 866-873.

Khosla, P. K. and Sharma, M. L. 1973. Cytological observations on some species of Setaria. The Nucleus 16: 38-41.

Mabberley, D. 1998. The Plant-Book (2nd ed.). Cambridge University Press, Cambridge.

Mehra, P. N., Khosla, P. K., Kohli, B. L. and Koonar, J. S. 1968. Cytological studies in the North Indian grasses. I. Research Bulletin of Panjab University (Science) 19: 157.

Olorode, O. 1975. Additional chromosome counts in Nigerian grasses. Brittonia 27: 63-68.

Sarkar, A. K., Chakraborty, M., Saha, N. C. and Das, S. K. 1976. In IOPB chromosome number reports LIV. Taxon 25: 631-649.

Schery, R. W. 1972. Plants for Man (2nd ed.). Prentice-Hall, Engelwood Cliffs, NJ.

Sindhe, A. N. R. 1977. In IOPB chromosome number reports LVI. Taxon 26: 257-274.

Singh, R. V. and Gupta, P. K. 1977. Cytological studies in the genus Setaria (Gramineae). Cytologia 42: $483-493$.

Sinha, R. R. P., Bhardwaj, A. K. and Singh, R. K. 1990. SOCGI plant chromosome number reports-IX. Journal of Cytology and Genetics 25: 140-143.

Spies, J. J. and Du Plessis, H. 1987. Chromosome studies on African plants. 5. Bothalia 17: 257-259. 